\title{
Penerapan SMOTE untuk Mengatasi Imbalance Class dalam Klasifikasi Television Advertisement Performance Rating Menggunakan Artificial Neural Network
}

\author{
Edi Sutoyo $^{\# 1}$, M. Asri Fadlurrahman ${ }^{\# 2}$ \\ \# Program Studi Sistem Informasi, Fakultas Rekayasa Industri, Telkom University \\ Jl. Telekomunikasi Jl. Terusan Buah Batu, Sukapura, Kec. Dayeuhkolot, Kota Bandung, Jawa Barat 40257 \\ 1edisutoyo@telkomuniversity.ac.id \\ ªsrifadlurrahman@student.telkomuniversity.ac.id
}

\begin{abstract}
Abstrak - Dalam data nyata, ada banyak situasi di mana jumlah instance di satu class jauh lebih sedikit daripada jumlah instance di class lain. Keadaan ini disebut sebagai masalah dataset tidak seimbang (imbalance class). Imbasnya kinerja klasifikasi biasanya menurun di beberapa aplikasi data mining. Pada penelitian ini, diidentifkasi bahwa dataset performansi rating iklan TV yang digunakan memiliki permasalahan imbalance class yang sangat besar dimana instance yang memiliki nilai rating tinggi, jauh lebih sedikit dibandingkan instance yang memiliki nilai rating kecil dan menengah. Sehingga diperlukan metode over-sampling untuk mengatasi permasalahan imbalance class tersebut. Metode yang dapat digunakan adalah Synthetic Minority Oversampling Technique (SMOTE). Untuk memvalidasi keefektifan model yang diusulkan, dilakukan dua skenario eksperimental yaitu: pertama algoritma ANN langsung digunakan untuk pemodelan tanpa mempertimbangkan ketidakseimbangan kelas, dan kedua dilakukan oversampling SMOTE untuk meningkatkan jumlah dataset agar mencapai dataset yang seimbang. Hasil eksperimen menunjukkan bahwa performansi ANN+SMOTE mencapai akurasi sebesar $87.06 \%$ dibandingkan ANN yang hanya sebesar $86.35 \%$. Penerapan Teknik SMOTE terbukti dapat mengatasi masalah ketidakseimbangan data dan mendapatkan hasil klasifikasi yang lebih baik.
\end{abstract}

Kata kunci - Artificial Neural Network, Classification, Data Mining, Imbalance Class, SMOTE

\section{PENDAhuluan}

Iklan adalah segala jenis presentasi non-pribadi dan penyiaran suatu ide/gagasan, barang, maupun jasa oleh penyedia sponsor tertentu yang berbayar, melalui media komunikasi baik itu cetak ataupun elektronik [1]. Setiap perusahaan yang mengiklankan produk atau jasa yang mereka tawarkan pasti menginginkan keuntungan dari penjualan dimasa mendatang. Untuk mencapai hal tersebut, perusahaan harus bisa mengetahui efektivitas iklan mereka.
Salah satu parameter yang dapat digunakan untuk mengukur efektivitas iklan adalah dengan rating iklan.

Rating adalah suatu nilai persentase 0 sampai 100 dari estimasi pasar media yang dapat dijangkau oleh iklan yang disiarkan. Rating biasanya diukur dengan performa iklan di masa lampau ataupun dari survei yang dilakukan [2]. Besarnya nilai rating dapat mempengaruhi nilai jual produk yang diiklankan. Biaya pemasukan iklan diharapkan untuk dapat menutupi biaya produksi iklan yang besar. Oleh karena itu, penentuan ads type dan alokasi waktu yang tepat sangat berpengaruh terhadap kesuksesan iklan yang ditampilkan. Untuk mengetahui ads type maupun alokasi waktu pengiklanan yang tepat, dapat dilakukan prediksi performance rating suatu iklan dengan menggunakan teknik data mining.

Data Mining dapat digunakan untuk menyimpulkan suatu informasi dari sekumpulan data yang berjumlah besar. Data mining melibatkan ilmu statistika, matematika, dan kecerdasan untuk mengidentifikasi informasi ([3], [4]). Salah satu teknik yang bisa digunakan untuk mengidentifikasi informasi dengan data mining adalah klasifikasi. Klasifikasi dapat mengklasifikasikan setiap item pada suatu dataset ke dalam kelas-kelas atau kelompok yang sudah didefinisikan sebelumnya. Tujuannya adalah untuk memprediksikan pengelompokan setiap data yang ada pada dataset [5]. Klasifikasi telah banyak digunakan dan dikembangkan hasilnya berupa pembaruan teori maupun implementasi pada real-world problems ([6]-[11]). Pada penelitian ini, teknik klasifikasi akan digunakan untuk mengidentifikasi data iklan ke dalam beberapa jenis/kelas rating.

Berdasarkan Dokare dan Kant [12] dilakukan penelitian untuk menganalisis performa antara algoritma Support Vector Machine (SVM), k-Nearest Neighbour (k-NN), dan Artificial Neural Network (ANN). Didapatkan hasil bahwa ANN merupakan metode yang lebih baik untuk digunakan dengan nilai akurasi maksimum 80\%. Dewi [13] 
melakukan penelitian perbandingan 5 algoritma data mining untuk prediksi keberhasilan pemasaran produk pada perbankan. Penelitian tersebut menunjukkan bahwa ANN menghasilkan akurasi tertinggi sebesar $89.71 \%$. Penelitian lain yaitu Saritas dan Yasar [6] dilakukan analisa performa algoritma ANN dan Naive Bayes untuk klasifikasi mendapatkan hasil akurasi $86.95 \%$ untuk ANN.

Dari beragam algoritma klasifikasi data mining, salah satu metode klasifikasi yang sering digunakan adalah Artificial Neural Network (ANN) [13]. ANN merupakan suatu struktur komputasi yang terinspirasi oleh sistem jaringan saraf biologis. ANN terdiri atas beberapa proses yang sederhana tetapi saling berkoneksi yang disebut dengan neuron. ANN dapat mengkomputasikan data berstruktur melalui proses learning dan training [14]. Salah satu algoritma learning yang dapat digunakan untuk identifikasi klasifikasi menggunakan ANN adalah algoritma Backpropagation. Algoritma Backpropagation dapat memperkecil tingkat error output dengan cara mengubah nilai bobot-bobotnya dalam arah mundur (backward) sesuai dengan perbedaan output dengan target yang diinginkan [15].

Dataset yang digunakan pada penelitian ini diperoleh dari sebuah perusahaan yang bergerak pada periklanan. Dataset yang digunakan berisikan data historis rating iklan yang diiklankan pada perusahaan tersebut yang bergerak sebagai perusahaan agensi iklan. Dalam data nyata, ada banyak situasi di mana jumlah instance di satu class jauh lebih sedikit daripada jumlah instance di class lain. Fenomena ini disebut sebagai masalah imbalance class, yang berdampak menurunnya kinerja algoritma klasifikasi di beberapa aplikasi data mining termasuk pengenalan pola medis, manajemen telekomunikasi, bioinformatika, dan kategorisasi teks. Sebagian besar model konvensional menetapkan kelas mayoritas ke data dan mengabaikan kelas minoritas karena kemiringan data. Untuk mengatasi permasalahan imbalance class, salah satu metode yang digunakan adalah sampling. Metode sampling melakukan modifikasi terhadap distribusi data antar kelas mayoritas dan kelas minoritas pada dataset training untuk menyeimbangkan jumlah data tiap kelas ([16]-[18]).

Pada tahap preprocessing data, diidentifkasi bahwa dataset yang digunakan pada penelitian ini memiliki permasalahan imbalance class yang sangat besar dimana instance data yang memiliki nilai rating besar $(>5)$ jauh lebih sedikit dibandingkan instance data yang memiliki nilai rating kecil/menengah $(<5)$. Sehingga diperlukan metode preprocessing untuk mengatasi permasalahan imbalance class tersebut. Salah satu teknik over-sampling yang dapat digunakan adalah Syntetic Minority Oversampling Technique (SMOTE). SMOTE dapat melakukan duplikasi data secara sintetis sehingga permasalahan distribusi data yang berbeda dapat diatasi [19]. Untuk memvalidasi keefektifan metode yang diusulkan, dilakukan dua skenario eksperimental: pertama, algoritma ANN langsung digunakan untuk pemodelan tanpa mempertimbangkan ketidakseimbangan kelas. Kemudian untuk skenario kedua, over-sampling SMOTE digunakan untuk meningkatkan jumlah dataset untuk mencapai dataset yang seimbang [2].

Berdasarkan penelitian sebelumnya didapatkan bahwa ANN lebih baik digunakan daripada algoritma yang lainnya. Oleh karena itu, penelitian ini menggunakan ANN untuk melakukan prediksi rating performa iklan televisi. Dengan adanya model prediksi ini, diharapkan bisa mendapatkan hasil prediksi yang dapat dijadikan bahan pertimbangan dalam pengambilan keputusan pembuatan iklan pada perikalan tersebut.

\section{LANDASAN TEORI}

\section{A. Data Mining}

Data mining adalah proses pemecahan masalah dengan cara menganalisis data untuk menemukan pola atau informasi yang tersembunyi dalam sekumpulan data. Proses-proses ini harus berupa proses yang otomatis atau semi-otomatis. Pola atau informasi yang diperoleh dapat digunakan untuk menjelaskan data kemudian membuat prediksi berdasarkan pola atau informasi tersebut [20].

Data mining juga sering dikenali dengan istilah Knowledge Discovery in Database (KDD) yang merupakan langkah penting dalam penemuan pengetahuan. Langkah - langkah yang dilakukan didalam proses data mining adalah sebagai berikut [3] :

1. Data Cleaning (menghilangkan noise pada data dan data yang tidak konsisten).

2. Data Integration (proses untuk menggabungkan data dari beragas sumber data menjadi satu).

3. Data Selection (proses dimana dilakukan pemilihan data yang relevan untuk dilakukan analisisnya).

4. Data Transformation (proses mentransformasikan data kedalam bentuk yang siap sebagai masukan algoritma data mining).

5. Data Mining (proses utama dimana algoritma data mining diaplikasikan untuk menemukan pola pada data).

6. Pattern Evaluation (proses untuk mengidentifikasi pola yang menarik dari data)

7. Knowledge Presentation (proses dimana hasil data mining divisualisasikan untuk ditampilkan).

\section{B. Klasifikasi}

Klasifikasi adalah salah satu fungsi dari data mining untuk mengelompokkan suatu item data kedalam kategori atau kelas-kelas yang sudah didefinisikan terlebih dahulu dengan tujuan untuk memprediksi secara akurat kelas/kategori yang sesuai untuk seluruh data yang ada pada dataset [5]. Pada klasifikasi, terdapat suatu variabel yang berfungsi sebagai label target. Model data mining memeriksa sekumpulan record, dimana tiap record menyimpan variabel label dari record tersebut, dan juga variabel input ataupun variabel prediktor [21].

Pertama, algoritma klasifikasi akan menguji dataset training yang berisikan variabel prediktor yang memiliki variabel label yang sudah diklasifikasi terlebih dahulu. Dengan demikian, algoritma akan "mempelajari" 
hubungan antara kombinasi variabel prediktor dengan variabel label. Kemudian, algoritma akan diberikan dataset testing yang hanya berisikan variabel prediktor yang tidak memiliki variabel label. Algoritmanya kemudian melakukan klasifikasi terhadap dataset testing berdasarkan "pengalaman" algoritma saat mengklasifikasi dataset training [21].

\section{Artificial Neural Network (ANN)}

ANN adalah suatu struktur komputasi yang didasarkan oleh sistem jaringan saraf biologis. ANN terdiri atas beberapa proses yang sederhana tetapi saling berkoneksi yang disebut dengan neuron. Proses ini terdiri dari pengumpulan data, analisis dan pemrosesan data, desain struktur jaringan, jumlah lapisan yang tersembunyi, inisialisasi, pelatihan jaringan, simulasi jaringan, penyesuaian bobot/bias, dan terakhir pengujian jaringan. ANN biasa digunakan untuk memproses kumpulan data yang besar, untuk dapat menyediakan informasi analisis yang dapat berguna untuk memprediksikan ataupun identifikasi klasifikasi suatu data [14].

Fungsi aktivasi merupakan fungsi yang digunakan pada jaringan saraf untuk mengaktifkan atau tidak mengaktifkan neuron. Karakteristik yang harus dimiliki oleh fungsi aktivasi jaringan perambatan balik antara lain harus kontinu, terdiferensial, dan tidak menurun secara monoton (monotonically non-decreasing) [22]. Fungsi aktivasi dibutuhkan oleh hidden layer pada ANN untuk membuat ANN menjadi non linear. Fungsi aktivasi dapat berupa fungsi linear, threshold, atau sigmoid. Fungsi sigmoid biasa digunakan karena fungsi ini mengombinasikan nearly linear behavior, curvilinear behavior, dan nearly constant behavior [21]. Fungsi aktivasi sigmoid dapat diketahui sebagai berikut:

$$
y=\sigma(x)=\frac{1}{\left(1+e x p^{-x}\right)}
$$

Setiap pola informasi input maupun output yang dimasukkan kedalam ANN akan diproses ke dalam neuron. Neuron tersebut terkumpul dalam 3 layer/lapisan seperti pada Gambar 1 berikut [14] :

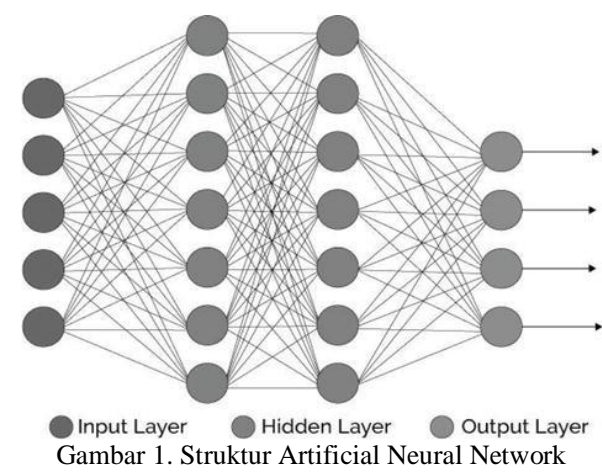

1. Input layer, pada lapisan ini berisikan neuron - neuron yang digunakan untuk menerima input untuk proses learning dan recognition dari ANN.
2. Hidden Layer, pada lapisan ini berisikan neuron neuron yang digunakan untuk mengganti kontribusi yang digunakan oleh neuron pada output layer.

3. Output Layer, pada lapisan ini berisikan neuron - neuron yang akan bereaksi terhadap data input yang diberikan.

Backpropagation merupakan algoritma pembelajaran yang terawasi dan biasanya digunakan oleh perceptron dengan banyak lapisan untuk mengubah bobot-bobot yang terhubung dengan neuron-neuron yang ada pada lapisan tersembunyinya. Algoritma backpropagation menggunakan error output untuk mengubah nilai bobotbobotnya dalam arah mundur (backward). Untuk mendapatkan error ini, tahap perambatan maju (feedforward) harus dikerjakan terlebih dahulu [23], [24].

Komputasi feed-forward atau forward pass adalah tahap yang berupa dua proses. Proses pertama adalah untuk menghitung nilai output dari neuron pada hidden layer, dan proses kedua adalah untuk menghitung nilai output dari neuron pada output layer. Nilai output pada tiap neuron dapat dihitung dengan rumus sebagai berikut [25] :

$$
y=\sigma\left(\sum_{i}^{j} W_{i j} X_{i j}\right)
$$

Keterangan:

$\sigma=$ fungsi sigmoid

$W=$ nilai bobot antara neuron

$X=$ nilai dari neuron input

$y=$ nilai output prediksi ANN.

Langkah selanjutnya adalah menghitung nilai error dari nilai output pada neuron yang ada pada output layer. Penghitungan nilai error dapat menggunakan nilai Mean Square Error (MSE). MSE adalah nilai error rata-rata dari seluruh record (neuron pada layer penghitungan) pada ANN dirumuskan sebagai berikut [26]:

$$
\delta_{i j}=\frac{\sum\left(t_{i j}-y_{i j}\right)^{2}}{\text { jumlah record }}
$$

Keterangan:

$\delta_{i j}=$ Error pada neuron $i j$

$t_{i j}=$ Nilai Output target pada neuron $i j$

$y_{i j}=$ nilai output prediksi ANN pada neuron $i j$.

Setelah nilai error diketahui, nilai tersebut akan digunakan untuk backward propagation dan mengubah nilai bobot. Pertama, nilai error akan dipropagasikan dari output layer ke hidden layer sehingga nilai bobot antara setiap neuron pada hidden layer dan output layer akan di diubah terlebih dahulu. Sebelum nilai bobot dapat diubah, dilakukan penghitungan nilai koreksi bobotnya [26] :

Keterangan :

$$
\Delta W_{i j}=\alpha \delta_{i j} y_{i j}
$$

$$
\Delta W_{i j}=\text { nilai koreksi bobot }
$$$$
\alpha \quad=\text { nilai learning rate }
$$

Langkah selanjutnya adalah melakukan propagasi balik dari hidden layer ke input layer untuk memperoleh nilai 
error sehingga dapat digunakan untuk mengubah nilai bobot antara setiap neuron pada input layer dan hidden layer. Hal yang paling utama untuk diingat adalah untuk tidak melakukan perubahan nilai bobot sebelum semua nilai error telah dihitung terlebih dahulu. Nilai bobot yang baru dapat diperoleh dengan menambahkan nilai bobot yang lama dengan nilai koreksi bobot [26] :

$$
W_{i j}(\text { new })=W_{i j}(\text { old })+\Delta W_{i j}
$$

Keempat tahapan ini kemudian dilakukan proses iterasi hingga ANN berhasil memenuhi Stopping Criteria, yaitu kondisi yang membuat algoritma akan berhenti melakukan proses training [21].

\section{Imbalance Class}

Imbalance class adalah kondisi distribusi antar kelas yang tidak seimbang pada suatu dataset, dimana salah satu kelasnya memiliki jumlah data yang sangat besar (kelas mayoritas) dibanding kelas lainnya (kelas minoritas) [27]. Perbedaan jumlah data yang besar antar kelas dapat mengakibatkan model klasifikasi sering tidak dapat memprediksikan kelas minoritas dengan tepat sehingga banyak data tes yang seharusnya berada pada kelas minoritas diprediksikan salah oleh model klasifikasi [28].

Untuk mengatasi permasalahan imbalance class, salah satu metode yang digunakan adalah sampling. Metode sampling melakukan modifikasi terhadap distribusi data antar kelas mayoritas dan kelas minoritas pada dataset training untuk menyeimbangkan jumlah data tiap kelas [29]. Salah satu metode sampling yang sering digunakan adalah Syntetic Minority Over-sampling Technique (SMOTE) [19].

\section{E. Synthetic Minority Over-sampling Technique (SMOTE)}

SMOTE adalah metode over-sampling dimana data pada kelas minoritas diperbanyak dengan menggunakan data sintetik yang berasal dari replikasi data pada kelas minoritas. Over-sampling pada SMOTE mengambil instance dari kelas minoritas lalu mencari $k$-nearest neighbor dari setiap instance, kemudian menghasilkan instance sintetik daripada mereplikasi instance kelas minoritas; oleh karena itu, dapat menghindari masalah overfitting yang berlebihan [19].

Algoritma yang bekerja pada SMOTE pertama akan mengambil nilai selisih antara vektor dari fitur pada kelas minoritas dan nilai nearest neighbor dari kelas minoritas lalu mengalikan nilai tersebut dengan angka acak antara 0 sampai 1. Selanjutnya, hasil kalkulasi tersebut ditambahkan dengan vektor fiturnya sehingga didapatkan hasil nilai vektor yang baru [30].

$$
X_{\text {new }}=X_{i}+\left(\widehat{X}_{l}-X_{i}\right) \times \delta
$$

Keterangan :

$$
\begin{array}{ll}
X_{i} & =\text { vektor dari fitur pada kelas minoritas } \\
\widehat{X}_{l} & =k \text {-nearest neighbors untuk } X_{i} \\
\delta & =\text { angka acak antara } 0 \text { sampai } 1
\end{array}
$$

\section{METODOLOGI PENELITIAN}

Dalam pembuatan model klasifikasi, metode yang digunakan adalah ANN. Klasifikasi tv rating pada pada penelitian ini menggunakan data rating iklan yang diperoleh dari PT. XYZ yang bergerak dalam industri periklanan, dengan jumlah data sebanyak 22.218 instance. Pada Gambar 2 berikut memberikan gambaran umum tentang metodologi penelitian yang dilakukan.

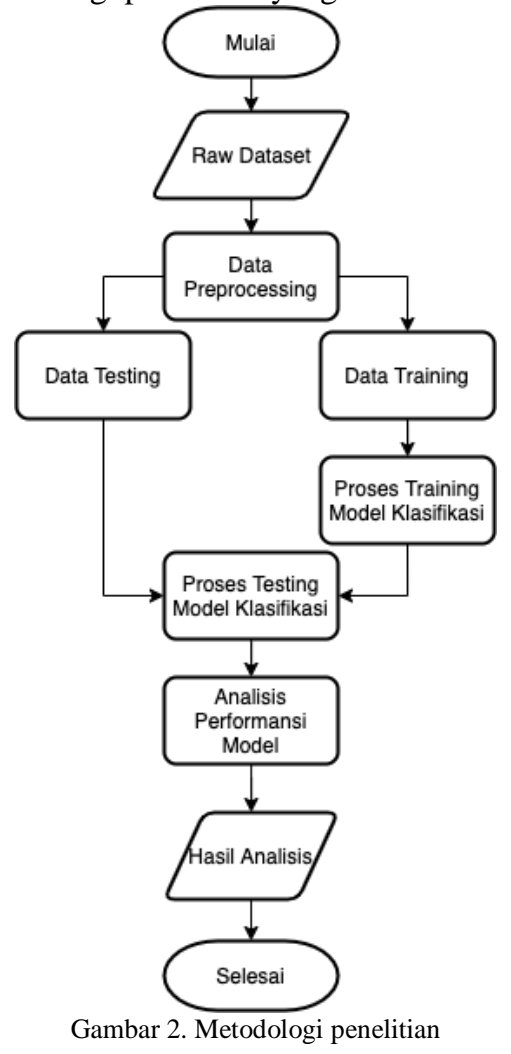

\section{HASIL DAN PEMBAHASAN}

\section{A. Pengumpulan Data}

Pengumpulan data yang akan diolah pada penelitian ini berasal dari data yang diperoleh pada aplikasi vislog PT. XYZ, yang merupakan data performa iklan pada kategori instant noodle periode bulan Oktober tahun 2019 sampai dengan bulan Desember tahun 2019. Distribusi data yang digunakan pada penelitian ini dapat ditunjukkan pada Tabel 1.

TABEL I

JUMLAH DATA PER-BULAN

\begin{tabular}{|l|l|}
\hline Bulan & Jumlah Baris \\
\hline Oktober & 6.735 \\
\hline November & 6.441 \\
\hline Desember & 9.042 \\
\hline Total & $\mathbf{2 2 . 2 1 8}$ \\
\hline
\end{tabular}

Dari data yang diperoleh terdapat atribut yaitu tanggal, channel, program, produk, jenis iklan, waktu mulai, durasi, 
biaya, dan TVR. Penjelasan dari atribut yang diperoleh akan dijelaskan pada Tabel 2.

TABEL II

PENJELASAN ATRIBUT DATA

\begin{tabular}{|c|c|c|}
\hline No & Atribut & Penjelasan \\
\hline 1 & Date & $\begin{array}{llll}\text { Tanggal penayangan dari iklan } \\
\text { tersebut }\end{array}$ \\
\hline 2 & Channel & $\begin{array}{l}\text { Channel televisi yang menayangkan } \\
\text { iklan tersebut }\end{array}$ \\
\hline 3 & Program & $\begin{array}{l}\text { Program televisi yang menayangkan } \\
\text { iklan tersebut }\end{array}$ \\
\hline 4 & Product & Nama produk yang diiklankan \\
\hline 5 & Ads Type & Jenis iklan yang ditayangkan \\
\hline 6 & $\begin{array}{l}\text { Start } \\
\text { Time }\end{array}$ & Waktu penayangan iklan dimulai \\
\hline 7 & Duration & Durasi lama penayangan iklan \\
\hline 8 & Cost & Biaya penayangan iklan \\
\hline 9 & $T V R$ & $\begin{array}{l}\text { Rating performa iklan yang } \\
\text { ditayangkan }\end{array}$ \\
\hline
\end{tabular}

Pada tahapan ini, dilakukan seleksi atribut yang akan digunakan pada penelitian ini. Metode information gain digunakan untuk menentukan keterkaitan antar atribut dengan label kelasnya. Atribut yang memiliki nilai gain di bawah 0.01 akan dihilangkan dan tidak akan digunakan pada penelitian ini. Dari hasil information gain yang ditampilkan pada Tabel 3, maka kolom atribut tidak akan digunakan dalam penelitian ini.

TABEL III

HASIL INFORMATION GAIN

\begin{tabular}{|l|l|}
\multicolumn{2}{|c}{ HASIL INFORMATION GAIN } \\
\hline Atribut & Information Gain \\
\hline Program & 0,450532 \\
\hline Cost & 0,326123 \\
\hline Start Time & 0,226721 \\
\hline Channel & 0.139214 \\
\hline Product & 0.032163 \\
\hline Ads Type & 0.021041 \\
\hline Duration & 0.015359 \\
\hline
\end{tabular}

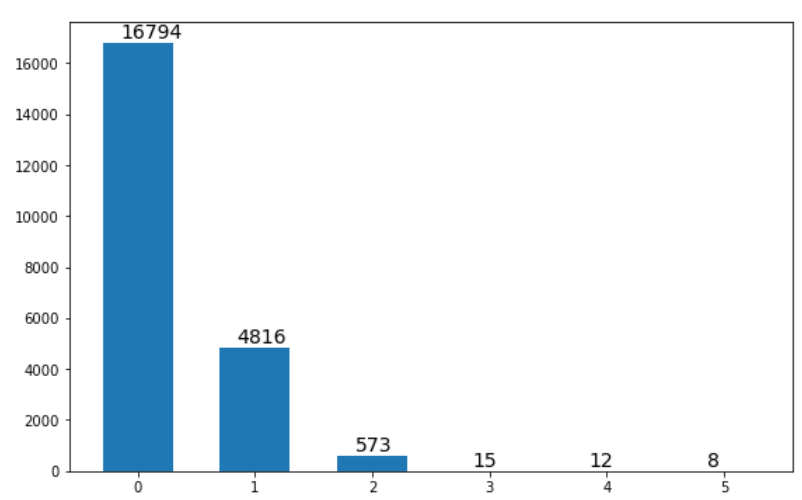

Gambar 3. Perbandingan jumlah instance setiap class

Pada Gambar 3, dapat dilihat bahwa terdapat sebaran distribusi data antar kelas yang sangat besar, dimana kelas TVR = 1 memiliki jumlah sampel sebanyak 13.483 data sedangkan kelas TVR $=5$ hanya memiliki jumlah sampel sebanyak 11 data. Dengan menggunakan SMOTE, maka sebaran distribusi data dapat menjadi seimbang karena pada kelas yang jumlah sampelnya lebih sedikit (kelas minoritas) akan diperbanyak jumlahnya dengan data sintetik yang dibuat oleh SMOTE.

Untuk menetapkan model klasifikasi dan mengujinya, setiap set data pertama-tama dibagi menjadi dua bagian, yaitu $80 \%$ digunakan untuk set pelatihan dan $20 \%$ digunakan untuk set pengujian. Set pelatihan digunakan untuk membangun model, sedangkan set pengujian digunakan untuk penilaian kinerja yang valid. Sebaran jumlah class dari dataset untuk masing-masing class sangat tidak seimbang, yaitu untuk class $=0$ berjumlah 16794 atau sebesar $75.587 \%$ dari total data, class $=1$ berjumlah 4816 atau sebesar $21.676 \%$, kemudian untuk class $=2$ berjumlah 573 data atau menyumbang $2.579 \%$, class $=3$ berjumlah 15 atau $0.068 \%$, sedangkan untuk class $=4$ hanya berjumlah 12 data atau $0.054 \%$ dan untuk class $=5$ hanya terdapat 8 data atau hanya $0.036 \%$.

Untuk memvalidasi keefektifan model yang diusulkan, dilakukan dua skenario eksperimental: pertama, algoritma ANN langsung digunakan untuk pemodelan tanpa mempertimbangkan ketidakseimbangan kelas. Kemudian untuk skenarion kedua, over-sampling SMOTE [19] digunakan untuk meningkatkan jumlah dataset untuk mencapai dataset yang seimbang. Teknik over-sampling ini dipilih karena telah diterapkan secara luas pada masalah ketidakseimbangan kelas. Kedua skenario tersebut kemudian dievaluasi menggunakan metriks evaluasi, yaitu accuracy, precision, recall dan F1-score. Model ANN yang diusulkan diimplementasikan di Win-Python 3.6.6 menggunakan library Keras. Semua observasi dilakukan pada komputer dengan Sistem Operasi Windows 10, Processor 2.5 GHz Quad-Core Intel Core i7, dan menggunakan RAM sebesar 16 GB.

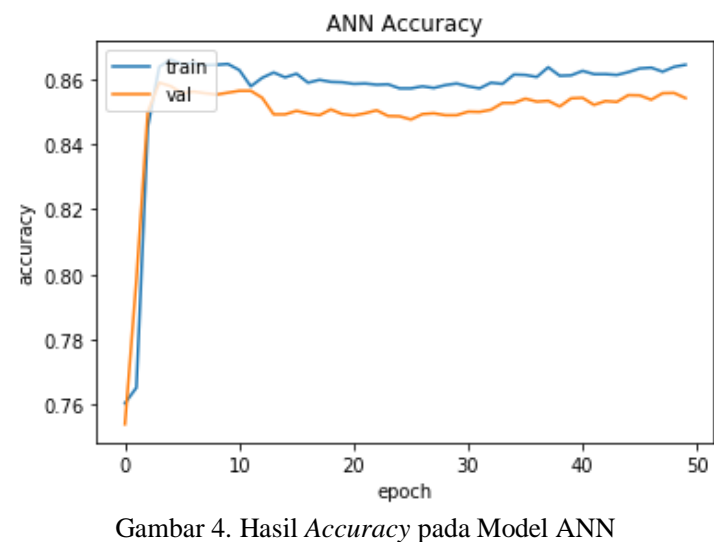

Hasil pada skenario pertama yang ditunjukkan pada Gambar 4 dan Gambar 5, menunjukkan bahwa model ANN untuk klasifikasi iklan rating TV cukup efektif dengan menghasilkan akurasi sebesar $86.35 \%$ dan loss sebesar 0.2630 pada proses pelatihan, sedangkan pada proses validasi menghasilkan akurasi sebesar $85.04 \%$ dan loss sebesar 0.2873.

Pada skenario kedua yang ditampilkan pada Gambar 6 dan Gambar 7 menunjukkan bahwa model 
ANN+SMOTE untuk klasifikasi rating iklan TV mampu memberikan hasil yang lebih baik dibandingkan dengan model ANN. Model ANN+SMOTE mampu menghasilkan akurasi sebesar $87.08 \%$ dan loss sebesar 0.2451 pada proses training. Sedangkan pada proses validasi, model ANN+SMOTE mampu menghasilkan akurasi sebesar $87.06 \%$ dan loss sebesar 0.2483. Sehingga, dengan menggunakan teknik SMOTE dapat meningkatkan akurasi sebesar $0.73 \%$ dan menurunkan loss sebesar 0.0179 pada proses pelatihan, serta dapat meningkatkan akurasi sebesar $2.2 \%$ dan menurunkan loss sebesar 0.039 pada proses validasi.

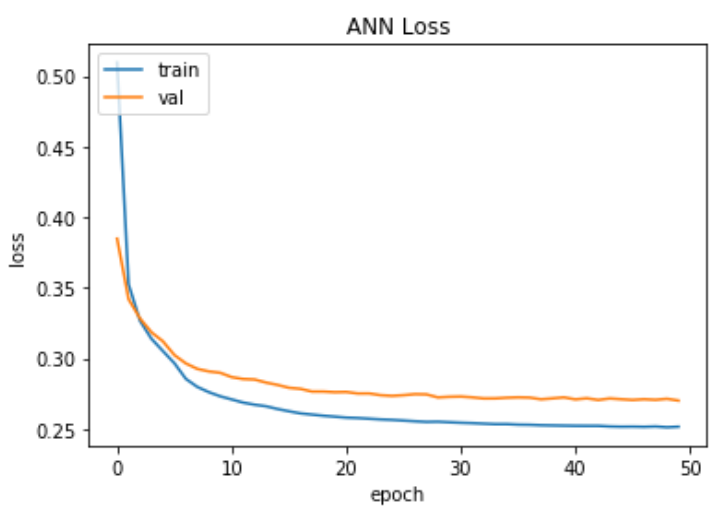

Gambar 5. Hasil Loss pada Model ANN

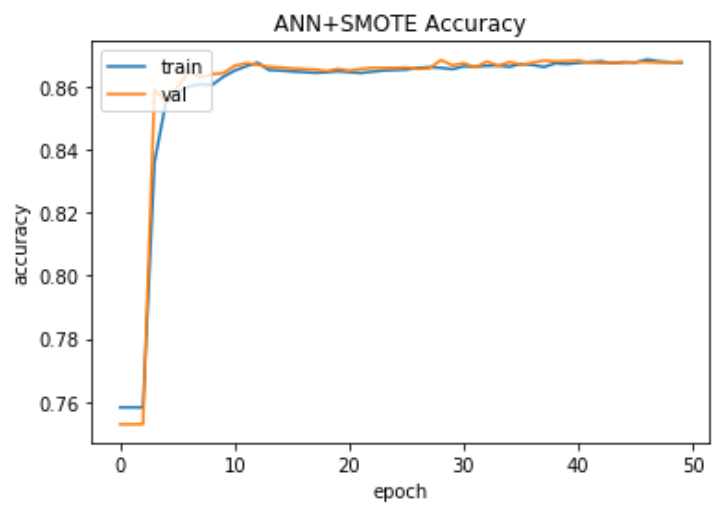

Gambar 6. Hasil Accuracy pada Model ANN+SMOTE

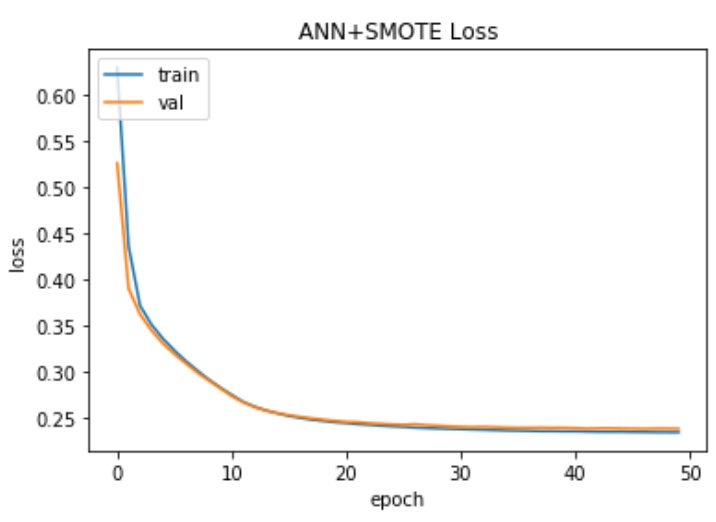

Gambar 7. Hasil Loss pada Model ANN+SMOTE
Pada skenario kedua menunjukkan bahwa teknik SMOTE selain meningkatkan akurasi dan menurunkan loss pada proses training maupun validasi, juga dapat mengurangi selisih jarak akurasi antara hasil training dengan hasil validasi yang hanya terdapat selisih $0.02 \%$ dan juga pada loss yang hanya terdapat selisih 0.0032 .

TABEL IV

HASIL EKSPERIMEN SECARA KESELURUHAN

\begin{tabular}{lcccc}
\hline \multirow{2}{*}{$\begin{array}{c}\text { Model } \\
\text { Algoritma }\end{array}$} & $\begin{array}{c}\text { Accuracy } \\
(\boldsymbol{\%})\end{array}$ & $\begin{array}{c}\text { Precision } \\
(\boldsymbol{\%})\end{array}$ & $\begin{array}{c}\text { Recall } \\
(\boldsymbol{\%})\end{array}$ & $\begin{array}{c}\text { F1- } \\
\text { Score } \\
(\%)\end{array}$ \\
\cline { 2 - 5 } & & & 84.5 & 81.0 \\
ANN & 86.35 & 79.0 & 86.0 & 82.5 \\
\hline
\end{tabular}

Secara keseluruhan, hasil eksperimen ditunjukkan pada Tabel 4. Tabel tersebut menunjukkan bahwa teknik gabungan yaitu ANN+SMOTE mempunyai kinerja lebih baik daripada teknik yang hanya menggunakan ANN ketika dievaluasi menggunakan metriks evaluasi yaitu accuracy, precision, recall dan F1-Score.

\section{KESIMPULAN}

Berdasarkan langkah penelitian yang telah dilakukan menunjukkan bahwa model ANN untuk klasifikasi performansi rating iklan TV cukup efektif dengan menghasilkan akurasi sebesar $86.35 \%$ dan loss sebesar 0.2630 pada proses pelatihan, sedangkan pada proses validasi menghasilkan akurasi sebesar $85.04 \%$ dan loss sebesar 0.2873. Sedangkan hasil eksperimen model ANN+SMOTE mampu memberikan hasil yang lebih baik dibandingkan dengan model ANN. Model ANN+SMOTE mampu menghasilkan akurasi sebesar $87.08 \%$ dan loss sebesar 0.2451 pada proses training. Sedangkan pada proses validasi, model ANN+SMOTE mampu menghasilkan akurasi sebesar $87.06 \%$ dan loss sebesar 0.2483 . Sehingga dapat disimpulkan bahwa penggunaan teknik SMOTE mampu meningkatkan akurasi sebesar $0.73 \%$ dan menurunkan loss sebesar 0.0179 pada proses pelatihan, serta meningkatkan akurasi sebesar $2.2 \%$ dan menurunkan loss sebesar 0.039 pada proses validasi untuk dataset yang terdapat imbalance class.

\section{REFERENSI}

[1] P. Kotler and K. L. Keller, MarkKotler, P., \& Keller, K. L. 2016.

[2] J. Pych, "Must Know Advertising Terms and Metrics | Bionic Advertising Systems," Bionic , 2016.

[3] J. Han, Data Mining: Concepts and Techniques (The Morgan Kaufmann Series in Data Management Systems). 2011.

[4] J. Han, M. Kamber, and J. Pei, Data mining: Data mining Concepts and Techniques, 3rd ed. Morgan Kaufmann, 2012.

[5] G. Kesavaraj and S. Sukumaran, "A study on classification techniques in data mining," in 2013 4th International Conference on Computing, Communications and Networking Technologies, ICCCNT 2013, 2013, doi: 10.1109/ICCCNT.2013.6726842.

[6] M. M. Saritas and A. Yasar, "Performance Analysis of ANN and Naive Bayes Classification Algorithm for Data Classification," Int. J. Intell. Syst. Appl. Eng., vol. 7, no. 2, pp. 88-91, Jun. 2019, doi: 10.18201//ijisae.2019252786.

[7] E. Sutoyo, A. Almaarif, and others, "Educational Data Mining for Predicting Student Graduation Using the $\mathrm{Na}\{\backslash$ "\i $\}$ ve Bayes 
Classifier Algorithm," J. RESTI (Rekayasa Sist. Dan Teknol. Informasi), vol. 4, no. 1, pp. 95-101, 2020.

[8] E. Sutoyo, R. R. Saedudin, I. T. R. Yanto, and A. Apriani, "Application of adaptive neuro-fuzzy inference system and chicken swarm optimization for classifying river water quality," in Proceeding - 2017 5th International Conference on Electrical, Electronics and Information Engineering: Smart Innovations for Bridging Future Technologies, ICEEIE 2017, 2018, vol. 2018January, pp. 118-122, doi: 10.1109/ICEEIE.2017.8328774.

[9] R. Rachmat and S. Suhartono, "Comparative Analysis of Single Exponential Smoothing and Holt's Method for Quality of Hospital Services Forecasting in General Hospital," Bull. Comput. Sci. Electr. Eng., vol. 1, no. 2, pp. 80-86, Aug. 2020, doi: 10.25008/bcsee.v1i2.8.

[10] H. Mudia, "Back Propagation Neural Network for Controlling Coupled Water Tank," Bull. Comput. Sci. Electr. Eng., vol. 1, no. 1, pp. 12-18, 2020, doi: 10.25008/bcsee.v1i1.4.

[11] S. N. W. Ahmad, M. A. Ismail, E. Sutoyo, S. Kasim, and M. S. Mohamad, "Comparative Performance of Machine Learning Methods for Classification on Phishing Attack Detection," Int. J., vol. 9 , no. $1.5,2020$

[12] I. Dokare and N. Kant, "Performance Analysis of SVM, k-NN and BPNN Classifiers for Motor Imagery," Int. J. Eng. Trends Technol., vol. 10, 2014.

[13] S. Dewi, "KOMPARASI 5 METODE ALGORITMA KLASIFIKASI DATA MINING PADA PREDIKSI KEBERHASILAN PEMASARAN PRODUK LAYANAN PERBANKAN," None, 2016.

[14] A. El-Shahat, Advanced Applications for Artificial Neural Networks. 2018.

[15] S. Haykin, Neural Networks and Learning Machines. 2008.

[16] R. Barandela, R. M. Valdovinos, J. S. Sánchez, and F. J. Ferri, “The imbalanced training sample problem: Under or over sampling?," in Joint IAPR international workshops on statistical techniques in pattern recognition $(S P R)$ and structural and syntactic pattern recognition (SSPR), 2004, pp. 806-814.

[17] G. E. Batista, R. C. Prati, and M. C. Monard, "A study of the behavior of several methods for balancing machine learning training data," ACM SIGKDD Explor. Newsl., vol. 6, no. 1, pp. 2029, 2004.

[18] H. M. Nguyen, E. W. Cooper, and K. Kamei, "Borderline oversampling for imbalanced data classification," Int. J. Knowl. Eng. Soft Data Paradig., vol. 3, no. 1, pp. 4-21, 2011.

[19] N. V Chawla, K. W. Bowyer, L. O. Hall, and W. P. Kegelmeyer, "SMOTE: Synthetic Minority Over-sampling Technique," J. Artif. Intell. Res., vol. 16, pp. 321-357, 2002.

[20] I. H. Witten, E. Frank, and M. a Hall, Data Mining: Practical Machine Learning Tools and Techniques (Google eBook). 2011.

[21] D. T. Larose, Discovering Knowledge in Data: An Introduction to Data Mining. 2005.

[22] E. B. Nababan and M. Zarlis, "Analisis Fungsi Aktivasi Sigmoid Biner Dan SIgmoid Bipolar Dalam Algoritma Backpropagation Pada Prediksi Kemampuan Siswa," J. Teknovasi, vol. 02, no. 1, pp. 103-116, 2015.

[23] D. Svozil, V. Kvasnicka, and J. Pospichal, "Introduction to multilayer feed-forward neural networks," Chemom. Intell. Lab. Syst., vol. 39, no. 1, pp. 43-62, 1997.

[24] R. Eldan and O. Shamir, "The power of depth for feedforward neural networks," in Conference on learning theory, 2016, pp. 907940.

[25] M. Cilimkovic, "Neural Networks and Back Propagation Algorithm," Fett.Tu-Sofia.Bg, pp. 3-7, 2010.

[26] G. Dhaneswara and V. (Jurusan I. K. U. K. P. S. Moertini, "Jaringan Saraf Tiruan Propagasi Balik Untuk Klasifikasi Data," Integr. FMIPA Unpar, 2004.

[27] H. He and E. A. Garcia, "Learning from imbalanced data," IEEE Trans. Knowl. Data Eng., vol. 21, no. 9, pp. 1263-1284, Sep. 2009, doi: 10.1109/TKDE.2008.239.

[28] Y. Sun, A. K. C. Wong, and M. S. Kamel, "Classification of imbalanced data: A review," Int. J. Pattern Recognit. Artif. Intell., vol. 23, no. 4, pp. 687-719, Jun. 2009, doi: $10.1142 / \mathrm{S} 0218001409007326$.
[29] G. Nguyen, A. Bouzerdoum, and S. L. Phung, "Learning pattern classification tasks with imbalanced data sets," Fac. Informatics Pap., Jan. 2009.

[30] S. T. Jishan, R. I. Rashu, N. Haque, and R. M. Rahman, "Improving accuracy of students' final grade prediction model using optimal equal width binning and synthetic minority over-sampling technique," Decis. Anal., vol. 2, no. 1, pp. 1-25, Dec. 2015, doi: 10.1186/s40165-014-0010-2. 